\title{
Multicellular Spheroid Culture Models: Applications in Prostate Cancer Research and Therapeutics
}

Daisuke Kurioka ${ }^{1}$, Akimitsu Takagi ${ }^{2}$, Misao Yoneda ${ }^{3}$, Yoshifumi Hirokawa ${ }^{3}$, Taizo Shiraishi ${ }^{3}$ and Masatoshi Watanabe ${ }^{1 *}$

${ }^{1}$ Laboratory for Medical Engineering, Division of Materials Science and Chemical Engineering, Graduate School of Engineering, Yokohama National University, Yokohama, Japan

${ }^{2}$ Yakult Central Institute for Microbiological Research, Tokyo, Japan

${ }^{3}$ Department of Pathologic Oncology, Institute of Molecular and Experimental Medicine, Mie University Graduate School of Medicine, Tsu, Japan

\begin{abstract}
Prostate cancer is one of the most prevalent cancers in men in Western countries, increasing in frequency with age through the most advanced years. Patients with localized prostate cancer are generally treated with radical prostectomy or radiation therapy. However, treatment of more malignant stages of the disease is problematic. Docetaxel-based chemotherapy in men with androgen-independent prostate cancer has been shown to have survival benefits but hormonal manipulation and other chemotherapeutic regimens, especially for androgen-independent lesions, have uncertain value. While research into the complex pathophysiology of advanced prostate cancer has led to identification of mechanisms and target molecules, it nevertheless remains necessary to develop new anticancer drugs. Cell culture models that mimic the structure and features of prostate cancer in vivo are necessary for research on tumor biology and design of novel anticancer therapies. In this context, 3-dimensional cultures of prostate cancer cells, including multicellular spheroid (MCS) cultures, started attracting increasing attention.
\end{abstract}

The present review provides up-to-date information regarding the significance of MCS culture for identification of mechanisms underlying human malignancies, including prostate cancer, and possible targets for prostate cancer therapies.

Keywords: Multicellular spheroid (MCS); Prostate cancer; Drug resistance; Epigenetics; Poly (ADP-ribose) polymerase 1 (PARP-1)

\section{Introduction}

Prostate cancer is the most common cancer in men from Western countries, and in particular from the United States of America [1]. Incidences and mortality rates of prostate cancer vary greatly among different geographic areas and ethnic groups. In Japan, the incidence is still low compared with Western countries. However, figures are increasing [2]. Thus, Prostate cancer is the most common cancer in men in Western countries, this place having been occupied by stomach cancer in 1995 [3]. Most patients present with clinically localized disease at the time of diagnosis, and prostate-specific antigen (PSA) and transrectal ultrasound are used to aid in biopsy. Several management options are available when prostate cancer is diagnosed at an early stage, including surgery, cryosurgery, radiation therapy, hormonal therapy, and watchful waiting. For advanced prostate cancers, surgical or medical ablation of androgens is regarded as the optimal first-line treatment [4]. In most patients treated with androgen deprivation, however, disease progression will occur and result in a stage referred to as hormone-refractory prostate cancer. Development of such hormonerefractory state involves a complex series of events such as selection and outgrowth of preexisting clones of androgen-independent cells, adaptive up-regulation of genes that contribute to cancer cell survival and growth after androgen ablation [5]. However, this process is not yet entirely understood.

Patients with hormone-refractory prostate cancer (HRPC) require new agents. Two trials with docetaxel-based chemotherapy demonstrated a significant improvement in overall survival, diseasefree survival, pain control, and PSA response [6,7]. Therefore, the United States Food and Drug Administration (FDA) has recommended 3-weekly docetaxel with prednisone as the first-line regimen for patients with HRPC. Despite the benefits, survival remains short and most patients actually do not benefit from docetaxel-based chemotherapy.
Effective second- and third-line treatments are still urgently needed and emerging new drugs clearly require evaluation. Although the effects of several anticancer drugs for prostate cancer have been evaluated in vitro and in animal experiments, most have had little or no impact on the survival of patients with HRPC and metastatic prostate cancer [8]. One of the reasons for discrepancies between in vivo and in vitro experiments is thought to be the disordered arrangement of cells within the tumor tissue, in clear contrast to the ordered arrangement in 2-dimensional (2D) cultures $[9,10]$. Thus, preclinical experimental models mimicking the clinical characteristics of prostate cancer are a high priority for testing new agents against prostate cancer. This review covers up-to-date information regarding the significance of 3-dimensional (3D) culture models, especially multicellular spheroid (MCS) culture models for identification of mechanisms in prostate cancer and target molecules for therapy.

\section{Three-dimensional culture models to study tumor biology}

The mechanism of drug resistance is associated with overexpression of P-glycoprotein (P-gp), a protein efflux pump. Multicellular resistance (MCR), which emerges as soon as cells have established contact with their microenvironment, is also involved [11]. The development of

*Corresponding author: Masatoshi Watanabe, M.D., Ph.D. Laboratory for Medical Engineering, Division of Materials Science and Chemical, Engineering, Graduate School of Engineering, Yokohama National University, 79-5 Tokiwadai, Hodogayaku, Yokohama, Japan; E-mail: mawata@ynu.ac.jp

Received November 06, 2010; Accepted January 26, 2011; Published February 04, 2011

Citation: Kurioka D, Takagi A, Yoneda M, Hirokawa Y, Shiraishi T, et al. (2011) Multicellular Spheroid Culture Models: Applications in prostate Cancer Research and Therapeutics. J Cancer Sci Ther 3: 060-065. doi:10.4172/1948-5956.1000059

Copyright: $\odot 2011$ Kurioka D, et al. This is an open-access article distributed under the terms of the Creative Commons Attribution License, which permits unrestricted use, distribution, and reproduction in any medium, provided the original author and source are credited. 
methods to clarify the mechanisms of tumor microenvironmentmediated drug resistance is clearly important. Two-dimensional culture models have been used widely as in vitro models for drug discovery in the field of cancer biology. They are easy and convenient to set up but lack tumor tissue features like tumor cell-tumor cell, tumor cell-stromal cell, and tumor cell-extracellular matrix (ECM) interactions as well as its typical structural architecture. Cancer cells are also labile, and their behavior can be modulated by the extracellular microenvironment and culture conditions. Comparison between the gene expression patterns of tumor tissues and immortalized cell lines has highlighted some transcriptional modifications in response to the in vitro environment [12-14]. Proteome analysis of 3D compared with 2D colon cancer cell cultures revealed a panel of alterations that may affect a wide variety of cellular functions related to protein synthesis, proliferation, regulation of the cytoskeleton, and apoptosis [15]. In 2D culture models, genes associated with cell cycling, metabolism, and turnover of macromolecules are up-regulated, showing that tumor cells adapt to growth needs and respond to growth factors in the culture medium $[12,16,17]$. On the other hand, tumor cells repress the expression of genes that may limit their growth potential or that are not necessary for in vitro growth. Thus, the value of $2 \mathrm{D}$ culture models for cancer research is limited. Importantly, it needs to be stressed that animal test systems are indispensable for pharmacokinetic and toxicological evaluation of candidate therapeutic compounds. However, the number of animal models used in the initial discovery of lead compounds has already begun to decline because of ethical and economic concerns, as well as inaccuracy for predicting clinical efficacy. The same is expected to happen with regard to target validation [18].

Some 3D culture models may satisfy the demands comparatively well and are thus promising tools for anticancer drug screening [19]. Notably, MCS can be cocultured with immune cells to evaluate the efficacy of immunotherapy, which progresses to future-oriented culture models [20]. The 3D culture models known at present are listed in (Table 1).

\section{MCS culture models of prostate cancer cells}

MCS culture is a $3 \mathrm{D}$ culture technique that closely mimics the tumor microenvironment. As for the case of other malignancies, MCS culture

\begin{tabular}{|c|c|c|}
\hline Model & Method & Description \\
\hline \multirow[t]{6}{*}{$\begin{array}{l}\text { Multicellular } \\
\text { spheroid }\end{array}$} & & $\begin{array}{l}\text { Spherical aggregate of cells in static or stirred } \\
\text { suspension culture }\end{array}$ \\
\hline & $\begin{array}{l}\text { Spontaneous } \\
\text { aggregation } \\
\text { Liquid-overlay }\end{array}$ & $\begin{array}{l}\text { A small number of cell types forms clusters } \\
\text { rather than strict spheroids Cells cultured on } \\
\text { the surface of an agarose gel matrix which } \\
\text { blocks attachment of the cells }\end{array}$ \\
\hline & $\begin{array}{l}\text { Microcarrier } \\
\text { beads }\end{array}$ & $\begin{array}{l}\text { Beads support aggregation of attached } \\
\text { dependent cells to form pseudo-spheroids in } \\
\text { gyratory and spinner flasks }\end{array}$ \\
\hline & Spinner flask & $\begin{array}{l}\text { Greater quantities of spheroids can be } \\
\text { cultivated in suspension than in liquid-overlay } \\
\text { cultures }\end{array}$ \\
\hline & Gyratory shaker & $\begin{array}{l}\text { Cell suspensions in Erlenmeyer flasks } \\
\text { containing a specific amount of medium are } \\
\text { rotated in a gyratory rotation incubator }\end{array}$ \\
\hline & $\begin{array}{l}\text { Rotary cell } \\
\text { culture }\end{array}$ & $\begin{array}{l}\text { The low shear environment provides an } \\
\text { advantage over static and stirred cultures, } \\
\text { allowing cells to aggregate, grow like 3D } \\
\text { structure and differentiate }\end{array}$ \\
\hline $\begin{array}{l}\text { Cellular } \\
\text { multilayer }\end{array}$ & & $\begin{array}{l}\text { Layers of cells cultured on top of a porous } \\
\text { membrane }\end{array}$ \\
\hline $\begin{array}{l}\text { Scaffold- } \\
\text { based culture }\end{array}$ & & $\begin{array}{l}\text { Cells cultured in synthetic 3D-simulating } \\
\text { matrices }\end{array}$ \\
\hline $\begin{array}{l}\text { Hollow-fiber } \\
\text { bioreactor }\end{array}$ & & $\begin{array}{l}\text { Cells cultured within a network of perfused } \\
\text { artificial capillaries }\end{array}$ \\
\hline
\end{tabular}

Table 1: Summary of three-dimensional culture models $[16,18]$. models of prostate cancer cells have been used to study prostate tumor biology, tumor cell-stromal cell interactions, and tumor cell responses to therapy [13,21-40] Recently, a comprehensive panel of spheroid culture models, including normal epithelial cells, their derivatives, and classical prostate cancer cell lines, has been reported [41]. As for MCS culture methods, spontaneous aggregation, liquid overlay, spinner flask, and rotating-wall vessel models have been used. Liquid overlay cultures exhibit enhanced functions relative to $2 \mathrm{D}$ cultures $[23,25,31]$. We have used round-bottomed plates coated with poly (2-hydroxyethyl methacrylate) (poly-HEMA; Sigma. Inc., St. Louis, MO) to monitor and manipulate arranged single spheroids at particular growth stages. Under some culture conditions, MCS of prostate cancer cell lines appear to be induced through enhanced expression of E-cadherin. PC-3 (human prostate cancer cell line) cells exhibiting abnormal E-cadherin-mediated cell-cell adhesion are unable to form compact spheroids or tight aggregates, yet loose aggregation in a liquid overlay culture has been reported [13,23,25-31,42]. Moreover, treatment with an anti-E-cadherin antibody inhibits spheroid formation of DU145 (human prostate carcinoma, epithelial-like cell line) and LNCaP (human prostate adenocarcinoma cell line) cells (Figure1). Besides its function in the formation of MCS, E-cadherin plays an important role in suppression of anoikis [43]. Aggregation of PC-3 cells rather than MCS formation occurs on agar- or poly-HEMA-coated plates; on Matrigel, a one-cell-thick spheroid is formed that partially induces normal differentiation of PC-3 cells $[23,25,28]$. These findings suggest that MCS formation may be dependent on tumor cell adhesion molecules and culture conditions. In addition, different MCS formation techniques may lead to different MCS phenotypes with different gene expression patterns [44]. Thus, it is essential to carefully select the most appropriate method.

DU-145 cells form fused compact spheroids, and both DU-145 and LNCaP cells grow at significantly slower rates than in 2D culture $[23,25]$. MCS of LNCaP cells exhibit disordered but tight cell-cell contacts, and their characteristics differ according to the location [13]. In two studies, the tumor cells of the intermediate zone were found to be positive for p27 and poly (ADP-ribose) polymerase 1 (PARP-1), but negative for Ki-67 (Figure 2a) $[13,45]$. These cells thus appear to be quiescent. All in all, the structure of a MCS is heterogeneous, with proliferating cells at the periphery and necrotic cells at the center [10,13]. Quiescent cells are viable but remain in a reversible state of growth arrest. The mechanism of their development within MCS remains unclear but appears to be a consequence of microenvironmental factors such as deprivation of growth factors and/or nutrients $[10,13,46]$. In general, slowgrowing tumors tend to be more drug- or ionizing radiation-resistant than rapidly growing tumors. There is no indication as to whether the proportion of quiescent cells is higher in MCS [11]. However, the presence and proportion of quiescent cells may be important determinants of the efficacy of chemotherapy

Differential expression of p18INK4c, p21waf1/cip1, and p27kip1 with respect to their location in the spheroids of EMT6 (mouse mammary tumor cell line) and MEL28 (human melanoma cell line) cells has also been reported: 21 waf1/cip 1 is found in the outer, proliferating cells, whereas p18INK4c and p27kip1 expression becomes elevated with increasing depth [47]. A decrease in all cell cycle regulatory proteins such as cyclin-dependent kinases (CDKs), CDK inhibitors (CKIs), and cyclins in the innermost spheroid fraction has also been observed [47]. These findings suggest molecular regulation of cell cycle progression in the inner region of spheroids due to microenvironmental stress and hypoxia, which evokes cell cycle arrest via the cyclin-dependent kinase inhibitor p27kip1 [48]. Quiescence was found due to marked 
cell contact-dependent up-regulation of p27kip1 in EMT6 spheroids, leading to drug or radiation resistance $[49,50]$. Ki-67 is a nuclear protein expressed during all active phases of the cell cycle. Therefore, it is expressed in proliferating but not in quiescent cells $[10,13,46]$. In contrast, a dramatic increase of p27kip1 was detected in every cell of the MCS in response to serum withdrawal, which is thought to be a specific environment [46]. In addition, up-regulation of P-gp in G0/G1-phase cells requires expression of $\mathrm{p} 27 \mathrm{kip} 1$ but not of $\mathrm{p} 21 \mathrm{waf1}$, suggesting that, under stress conditions (for instance, in hypoxia), p27kip1 contributes to a cell cycle arrest that is essential for cell survival, whereas P-gp contributes to cell survival by helping detoxify waste products [51].

PARPs are enzymes present in eukaryotes; these enzymes are involved in cell signaling through poly (ADP-ribosyl) ation of DNAbinding proteins [52,53]. By catalyzing the addition of ADP-ribose units to DNA, histones, and various DNA repair enzymes, they play multifunctional roles in many cellular processes. PARP-1 (EC 2.4.2.30) was the first of this family to be described in association with cellular responses to DNA damage [52,53]. PARP- 1 has a critical role in the repair of DNA single-strand breaks (SSB) through excision repair pathway. In addition, PARP-1 binds to DNA double-strand breaks (DSB) and activates several proteins involved in homologous recombination repair and nonhomologous end-joining pathways. Besides being involved in DNA repair, PARP can also act as a mediator of cell death [53]. Extensive DNA damage is known to trigger PARP overactivation with consequent extensive NAD consumption through ADP-ribose polymer synthesis, leading to ATP depletion and induction of necrosis.

In human malignancies, increased expression of PARP-1 has been reported in Ewing's sarcomas and in malignant lymphomas; conversely, decreased PARP-1 expression has been found in breast cancer and several other cell lines [53]. High PARP expression in prostate cancer cell lines compared to benign cell lines has already been reported, in which greater than $90 \%$ of $\mathrm{LNCaP}$ cells showed positivity for PARP before and after treatment with $\mathrm{H} 2 \mathrm{O} 2$ [54]. In LNCaP spheroids, expression of PARP-1 was detected and confined to the intermediate zone (Figure 2a) $[37,45]$, but real-time PCR demonstrated that expression of PARP-1 in $2 \mathrm{D}$ cultures is higher than in spheroid cultures. The specific location means that PARP maycontribute to the characteristics of the quiescent cells within the LNCaP spheroids, being linked with the target molecule in prostate cancer treatments. However, [55] reported that in glioma spheroids, PARP expression, which is initially diffuse, becomes confined to the outer proliferative zone, paralleling the expression of Ki-67. The authors speculated that this phenomenon might be consistent with a role for PARP in cell proliferation and determination of the biological behavior of gliomas.

Epigenetic mechanisms that can affect gene expression without altering the actual sequence of DNA include DNA methylation,

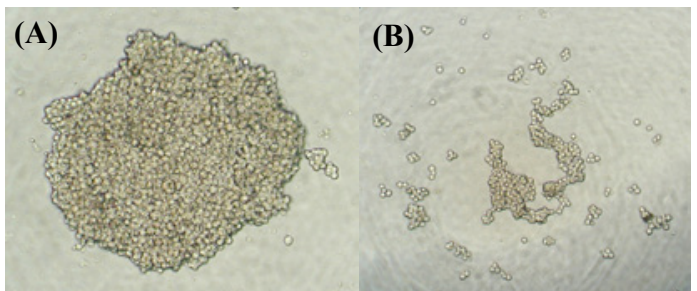

Figure 1: Role of E-cadherin in the formation of a LNCaP spheroid. (A) LNCaP cells form spheroids when cultured on poly-HEMA-coated dishes. (B) Treatment with an anti- E-cadherin antibody (HECD-1) inhibits LNCaP spheroid formation (Takagi et al., unpublished data).
(A)

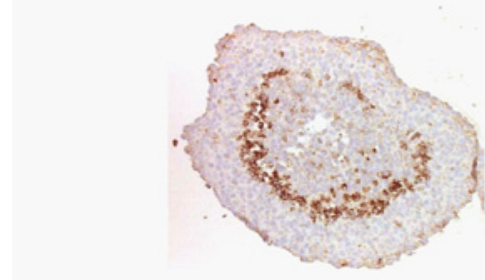

(B)

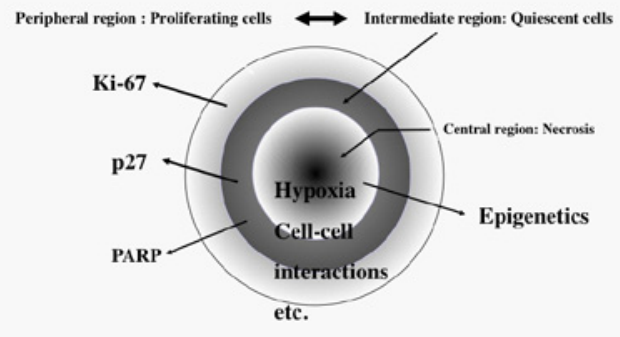

Figure 2: Localization of PARP-1 in a LNCaP spheroid and structure of a multicellular spheroid (MCS). (A) A section of a 7-day spheroid was stained with an anti-PARP-1 antibody (A6.4.12; Serotec, Oxford, UK). There is the intermediate zone with PARP immunostaining. (B) Structure of a MCS and characteristics of the tumor microenvironment. The structure of the spheroid favors genetic and epigenetic alterations.

RNA-associated silencing, and histone modification. These phenomena importantly affect gene expression during development [56]. Methylation of the C5 position of cytosine residues in DNA is recognized as a particularly important epigenetic silencing mechanism. Histone modification is another important epigenetic mechanism that determines their interactions with other proteins, thereby regulating chromatin structure and remodeling. DNA methylation and histone modifications related to chromatin remodeling have been intensively analyzed in various tumor types [57]. Thus, it is interesting to examine the epigenetic state of cancer cells in spheroids. [58] found that, similar to spheroids, TSUPr1 cells dynamically change their methylation patterns and the expression of E-cadherin as a function of the cellular microenvironment. They distinctively speculated that the cellular microenvironment selects for cells that have an appropriate methylation pattern, and that spheroid formation may increase the transcriptional expression E-cadherin, which in turn may drive regional hypomethylation of densely methylated $\mathrm{CpG}$ islands. This finding is very interesting because a methylation-regulated gene in a spheroid culture changes within a few days as compared to $2 \mathrm{D}$ cultures. A recent study by [59] has shown that increased levels of heterochromatin in spheroids characterized by histone $\mathrm{H} 3$ deacetylation and increased heterochromatin protein $1 a$ expression result in improved radiation survival and reduced numbers of DNA DSBs and lethal chromosome aberrations. A previous report showed that 3D growth of mammary epithelial cells reduced histone $\mathrm{H} 3$ and $\mathrm{H} 4$ acetylation and gene expression, although ECM-controlled cell shape was discussed [60]. Few studies about DNA methylation in spheroids have been reported. Similarly, little is known about the action of DNA methyltransferase (DNMT) enzymes. However, preliminary data showed that there are no significant differences in long interspersed nucleotide element 1 (LINE1) hypomethylation between 2D culture and MCS of LNCaP cells [37]. 
The microenvironment of solid tumors such as prostate cancer is characterized by hypoxia, low extracellular $\mathrm{pH}$, and nutrient deprivation. Under hypoxia, tumor cells increase expression of various genes, for instance those contributing to angiogenesis, partially through hypoxia-induced factor 1 (HIF-1). On the other hand, genes involved in cellular adhesion and DNA repair are decreased [61]. Down-regulation of mutL homologue 1 (MLH-1) in 2D cultures of EMT-6 cells under hypoxic conditions has been detected, with PM2 expression being unchanged [62]. However, down-regulation of PM2 was detected in EMT-6 spheroids. These results suggest that tumors can down-regulate DNA mismatch repair as a result of a series of microenvironmental factors, which results in increased resistance to alkylating agents. It has been hypothesized that hypoxia may influence local epigenetic alterations, leading to inappropriate silencing and reawakening of cancer genes [63]. A reduction of 5-methylcytosine in xenografts compared to the levels in the same cancer cell lines in vitro has been reported, providing direct evidence that epigenetic events in solid tumors may be modulated by microenvironmental stress [64]. In several mammalian cell lines, hypoxia increases globaldimethylated histone H3 lysine 9 (H3K9me2) expression through histone methyltransferase G9a, leading to inhibition of gene expression [64].

These findings suggest that epigenetic alterations in spheroids may be linked to their microenvironment. Whether activation or stimulation of anticancer drug resistance-related genes such as MDR-1 is brought about by epigenetic events is an intriguing possibility that needs to be analyzed.

\section{Applications to prostate cancer therapy}

Like solid tumors in vivo, MCS is characterized by hypoxic regions, The presence of hypoxic tumor microenvironment correlates with increased tumor invasiveness, metastases, and resistance to chemotherapy and radiotherapy [65]. Chemotherapeutic drug resistance in cancer cells under hypoxia is partially caused by reduced toxicity because of the absence of molecular oxygen. Hypoxia and nutrient deprivation can also promote mitochondrial reactive oxygen species (ROS) production, which result in modulation of ROS levels and energy metabolism to activate many signalling pathways leading to HIF family protein stabilization and activation [66]. Chemotherapeutic drug resistance is caused by HIF family-induced inhibition of cell cycle progression and proliferation.

Androgen ablation leads to an initial favorable response in patients. However, most relapse with an aggressive form of the disease known as castration-resistantor hormone-refractory prostate cancer. As critical molecular events that lead to prostate cancer cell resistance to androgen-deprivation therapy have been reported, there is also a possibility that hypoxia may be involved in the transition to androgen independence. Crosstalk between the androgen receptor and HIF-1 $\alpha$ in prostate cancer cells has been reported [67]. Thus, methods of targeting the microenvironment, especially hypoxia, have been investigated, e.g., to increase the oxygen supply to the tumor hypoxic area, to exploit the microenvironment by using bioreductive drugs, and to exploit the biological response to hypoxia by targeting HIF-1a.

PARP has attracted considerable attention as a therapeutic target for various diseases including cancer. Enhanced PARP-1 expression and/ or its activity has been shown in several tumor cell lines, contributing to resistance to genotoxic stress and ability to survive exposure to DNA-damaging agents [52,53]. Inhibition of PARP-1 thus enhances the efficiency of alkylating agents and ionizing radiation [53]. These results have stimulated the development of specific PARP-1 inhibitors as potential chemoand radiosensitizers. Several small-molecule
PARP inhibitors have indeed been synthesized and introduced into the clinic for treatment of cancer patients [53]. Research into breast cancer 2 susceptibility protein (BRCA2)-deficient cells, which are highly sensitive to inhibitors of PARP, has provided the basis for new therapeutic approaches [53]. Recently, a PARP inhibitor has been reported to radiosensitize DU-145 cells under hypoxia [68]. Like PARP, other proteins expressed by quiescent cells in MCSs may constitute targets for prostate cancer therapy.

The cancer stem cell (CSC) theory has emerged as a paradigm shift in our understanding of cancer as a disease of stem cells. A small subset of cancer cells within the tumor mass has the exclusive capacity to divide and expand the CSC pool and to differentiate into nontumorigenic, more differentiated cancer cell lineages. The existence of these small subsets of cells is responsible for tumor recurrence and metastasis. Thus, effective therapeutics should target rare CSCs that sustain tumor malignancy [69]. Such small subsets have been detected not only in malignancies of the blood but also in solid tumors in the brain, breast, and prostate, among others. Recent studies with prostate cells have also shown that nonmalignant immortalized cell lines and malignant cell lines contain a subset of cells with stem cell properties. In the spheroid culture system, nonmalignant and malignant human hTERT-immortalized prostate epithelial cells have been reported to maintain high CD133 expression [70]. The spheroid culture methods appear to contribute to the identification of CSCs from the prostate, which may be a new target for prostate cancer therapy.

\section{Summary}

MCS culture models have become a mainstream culture model for tumor biology and identification of anticancer resistance mechanisms as an alternative to the classical 2D culture models that poorly reflect the structural characteristicsseen in vivo. MCS culture models better mimic the growth characteristics of in vivo solid tumors. Like other solid tumors, prostate cancer creates a microenvironment characterized by hypoxia, acidosis, and nutrient deprivation, which collectively lead to tumor genetic and adaptive changes (Figure 2b). The tumor microenvironment correlates with prostate cancer invasiveness, metastasis, and resistance to radiotherapy and chemotherapy. Hypoxia may also be involved in the transition of prostate cancer to androgen independence. MCS culture models are a good model for understanding the mechanisms of resistance to chemotherapy, radiotherapy, and androgen ablation, and discovery of new targets for prostate cancer, especially androgen-independent cancer. Our review has highlighted the characteristics of prostate cancer MCS (p27 and PARP expression, and epigenetics), and underlined the tumor microenvironment as target for prostate cancer therapy. MCS culture models appear to contribute to the identification of CSCs from the prostate.

Further studies are needed to clarify mechanisms such as epigenetic regulation, to better characterize the formation of MCS, and to apply this knowledge into prostate cancer biology and the discovery of new targets for prostate cancer.

\section{Acknowledgments}

This work was supported in part by a Grant-in-Aid for Scientific Research from the Ministry of Education, Culture, Sports, Science and Technology, and a Grant-inAid from the Yokohama National University Global COE Program.

\section{References}

1. Jemal A, Siegel R, Ward E, Hao Y, Xu J, et al. (2008) Cancer statistics, 2008. CA Cancer J Clin 58: 71-96.

2. Watanabe M, Nakayama T, Shiraishi T, Stemmermann GN, Yatani R (2000) Comparative studies of prostate cancer in Japan versus the United States: A review. Urol Oncol 5: 274-283. 
Citation: Kurioka D, Takagi A, Yoneda M, Hirokawa Y, Shiraishi T, et al. (2011) Multicellular Spheroid Culture Models: Applications in prostate Cancer Research and Therapeutics. J Cancer Sci Ther 3: 060-065. doi:10.4172/1948-5956.1000059

3. Tabata N, Ohno Y, Matsui R, Sugiyama H, Ito Y, et al. (2008) Partial cancer prevalence in Japan up to 2020: estimates based on incidence and survival data from population-based cancer registries. Jpn J Clin Oncol 38: 146-157.

4. Bhandari MS, Petrylak DP, Hussain M (2005) Clinical trials in metastatic prostate cancer-has there been real progress in the past decade? Eur $\mathrm{J}$ Cancer 41: 941-953

5. So A, Gleave M, Hurtado-Col A, Nelson C (2005) Mechanisms of the development of androgen independence in prostate cancer. World $\mathrm{J}$ Urol 23 $1-9$

6. Petrylak DP, Tangen CM, Hussain MH, Lara PN Jr, Jones JA, et al. (2004) Docetaxel and estramustine compared with mitoxantrone and prednisone for advanced refractory prostate cancer. N Engl J Med 351: 1513-1520.

7. Tannock IF, de Wit R, Berry WR, Horti J, Pluzanska A, et al. (2004) Docetaxe plus prednisone or mitoxantrone plus prednisone for advanced prostate cancer. N Engl J Med 351: 1502-1512.

8. Diaz M, Patterson SG (2004) Management of androgen-independent prostate cancer. Cancer Control 11: 364-373.

9. Sutherland RM, McCredie JA, Inch WR (1971) Growth of multicell spheroids in tissue culture as a model of nodular carcinomas. J Natl Cancer Inst 46: 113120.

10. Hirschhaeuser F, Menne H, Dittfeld C, West J, Mueller-Klieser W, et al. (2010) Multicellular tumor spheroids: an underestimated tool is catching up again. $J$ Biotechnol 148: 3-15

11. Desoize B, Jardillier J (2000) Multicellular resistance: a paradigm for clinical resistance? Crit Rev Oncol Hematol 36: 193-207.

12. Birgersdotter A, Sandberg R, Ernberg I (2005) Gene expression perturbation in vitro--a growing case for three-dimensional (3D) culture systems. Semin Cancer Biol 15: 405-412.

13. Takagi A, Watanabe M, Ishii Y, Morita J, Hirokawa Y, Matsuzaki T, et al. (2007) Three-dimensional cellular spheroid formation provides human prostate tumor cells with tissue-like features. Anticancer Res 27: 45-53.

14. De Witt Hamer PC, Van Tilborg AA, Eijk PP, Sminia P, Troost D, et al. (2008) The genomic profile of human malignant glioma is altered early in primary cell culture and preserved in spheroids. Oncogene 27: 2091-2096.

15. Gaedtke L, Thoenes L, Culmsee C, Mayer B, Wagner E (2007) Proteomic analysis reveals differences in protein expression in spheroid versus monolayer cultures of low-passage colon carcinoma cells. J Proteome Res 6: 4111-4118.

16. Kim JB (2005) Three-dimensional tissue culture models in cancer biology Semin Cancer Biol 15: 365-377.

17. Rodríguez-Enríquez S, Gallardo-Pérez JC, Avilés-Salas A, Marín-Hernández A, Carreño-Fuentes L, et al. (2008) Energy metabolism transition in multicellular human tumor spheroids. J Cell Physiol 216: 189-197.

18. Kunz-Schughart LA, Freyer JP, Hofstaedter F, Ebner R (2004) The use of 3-D cultures for high-throughput screening: the multicellular spheroid model. J Biomol Screen 9: 273-285.

19. Burdett E, Kasper FK, Mikos AG, Ludwig JA (2010) Engineering tumors: a tissue engineering perspective in cancer biology. Tissue Eng Part B Rev 16 351-359.

20. Gottfried E, Kunz-Schughart LA, Andreesen R, Kreutz M (2006) Brave little world: spheroids as an in vitro model to study tumor-immune-cell interactions. Cell Cycle 5: 691-695.

21. Donaldson JT, Tucker JA, Keane TE, Walther PJ, Webb KS (1990) Characterization of a new model of human prostatic cancer: the multicellular tumor spheroid. Int J Cancer 46: 238-244.

22. Ingram M, Techy GB, Saroufeem R, Yazan O, Narayan KS, et al. (1997) Threedimensional growth patterns of various human tumor cell lines in simulated microgravity of a NASA bioreactor. In Vitro Cell Dev Biol Anim 33: 459-466.

23. Hedlund TE, Duke RC, Miller GJ (1999) Three-dimensional spheroid cultures of human prostate cancer cell lines. Prostate 41: 154-165.

24. O'Connor KC (1999) Three-dimensional cultures of prostatic cells: tissue models for the development of novel anti-cancer therapies. Pharm Res 16 : 486-493.

25. Frankel A, Man S, Elliott P, Adams J, Kerbel RS (2000) Lack of multicellular drug resistance observed in human ovarian and prostate carcinoma treated with the proteasome inhibitor PS-341. Clin Cancer Res 6: 3719-3728.

26. Clejan S, O'Connor K, Rosensweig N (2001) Tri-dimensional prostate cell cultures in simulated microgravity and induced changes in lipid second messengers and signal transduction. J Cell Mol Med 5: 60-73.

27. Enmon RM Jr, O'Connor KC, Lacks DJ, Schwartz DK, Dotson RS (2001) Dynamics of spheroid self-assembly in liquid-overlay culture of DU 145 human prostate cancer cells. Biotechnol Bioeng 72: 579-591.

28. Lang SH, Stark M, Collins A, Paul AB, Stower MJ, Maitland NJ (2001) Experimental prostate epithelial morphogenesis in response to stroma and three-dimensional Matrigel culture. Cell Growth Differ 12: 631-640.

29. Enmon RM Jr, O'Connor KC, Song H, Lacks DJ, Schwartz DK (2002) Aggregation kinetics of well and poorly differentiated human prostate cance cells. Biotechnol Bioeng 80: 580-588.

30. Mitrofanova E, Hagan C, Qi J, Seregina T, Link C Jr (2003) Sodium iodide symporter/radioactive iodine system has more efficient antitumor effect in three-dimensional spheroids. Anticancer Res 23: 2397-2404.

31. Khoei S, Goliaei B, Neshasteh-Riz A, Deizadji A (2004) The role of heat shock protein 70 in the thermoresistance of prostate cancer cell line spheroids. FEBS Lett 561: 144-148.

32. Song H, David O, Clejan S, Giordano CL, Pappas-Lebeau H, et al. (2004a) Spatial composition of prostate cancer spheroids in mixed and static cultures. Tissue Eng 10: 1266-1276.

33. Song H, Jain SK, Enmon RM, O'Connor KC (2004b) Restructuring dynamics of DU 145 and LNCaP prostate cancer spheroids. In Vitro Cell Dev Biol Anim 40: $262-267$

34. O'Connor KC, Venczel MZ (2005) Predicting aggregation kinetics of DU 145 prostate cancer cells in liquid-overlay culture. Biotechnol Lett 27: 1663-1668.

35. Wang R, Xu J, Juliette L, Castilleja A, Love J, et al. (2005) Three-dimensiona co-culture models to study prostate cancer growth, progression, and metastasis to bone. Semin Cancer Biol 15: 353-64

36. Jung V, Wullich B, Kamradt J, Stöckle M, Unteregger G (2007) An improved in vitro model to characterize invasive growing cancer cells simultaneously by function and genetic aberrations. Toxicol In Vitro 21: 183-190.

37. Watanabe M, Takagi A (2008) Biological behavior of prostate cancer cells in 3D culture systems. Yakugaku Zasshi 128: 37-44.

38. Pearson JF, Hughes S, Chambers K, Lang SH (2009) Polarized fluid movemen and not cell death, creates luminal spaces in adult prostate epithelium. Cell Death Differ 16: 475-482.

39. Chu JH, Yu S, Hayward SW, Chan FL (2009) Development of a threedimensional culture model of prostatic epithelial cells and its use for the study of epithelial-mesenchymal transition and inhibition of PI3K pathway in prostate cancer. Prostate 69: 428-442.

40. Hsiao AY, Torisawa YS, Tung YC, Sud S, Taichman RS, et al. (2009) Microfluidic system for formation of $\mathrm{PC}-3$ prostate cancer co-culture spheroids. Biomaterials 30: 3020-3027.

41. Härmä V, Virtanen J, Mäkelä R, Happonen A, Mpindi JP, et al. (2010) A comprehensive panel of three-dimensional models for studies of prostate cancer growth, invasion and drug responses. PLoS One 5: e10431.

42. Mitchell S, Abel P, Ware M, Stamp G, Lalani E (2000) Phenotypic and genotypic characterization of commonly used human prostatic cell lines. BJU Int 85: 932

43. Kang HG, Jenabi JM, Zhang J, Keshelava N, Shimada H, et al. (2007) E-cadherin cell-cell adhesion in ewing tumor cells mediates suppression of anoikis through activation of the ErbB4 tyrosine kinase. Cancer Res 67: 3094 3105.

44. Steadman K, Stein WD, Litman T, Yang SX, Abu-Asab M, et al. (2008) PolyHEMA spheroids are an inadequate model for the drug resistance of the intractable solid tumors. Cell Cycle 7: 818-829.

45. Muggia FM, Peters GJ, Landolph JR Jr (2009) XIII International Charles Heidelberger Symposium and 50 Years of Fluoropyrimidines in Cancer Therapy Held on September 6 to 8, 2007 at New York University Cancer Institute, Smilow Conference Center. Mol Cancer Ther 8: 992-999.

46. Mellor HR, Ferguson DJ, Callaghan R (2005) A model of quiescent tumou 
Citation: Kurioka D, Takagi A, Yoneda M, Hirokawa Y, Shiraishi T, et al. (2011) Multicellular Spheroid Culture Models: Applications in prostate Cancer Research and Therapeutics. J Cancer Sci Ther 3: 060-065. doi:10.4172/1948-5956.1000059

microregions for evaluating multicellular resistance to chemotherapeutic drugs. Br J Cancer 93: 302-309.

47. LaRue KE, Khalil M, Freyer JP (2004) Microenvironmental regulation of proliferation in multicellular spheroids is mediated through differentia expression of cyclin-dependent kinase inhibitors. Cancer Res 64: 1621-1631.

48. Gardner LB, Li Q, Park MS, Flanagan WM, Semenza GL, et al. (2001) Hypoxia inhibits $\mathrm{G} 1 / \mathrm{S}$ transition through regulation of p27 expression. J Biol Chem 276: 7919-7926.

49. St Croix B, Flørenes VA, Rak JW, Flanagan M, Bhattacharya N, et al. (1996) Impact of the cyclin-dependent kinase inhibitor p27Kip1 on resistance of tumor cells to anticancer agents. Nat Med 2: 1204-1210.

50. St Croix B, Sheehan C, Rak JW, Flørenes VA, Slingerland JM, et al. (1998) E-Cadherin-dependent growth suppression is mediated by the cyclindependent kinase inhibitor p27(KIP1). J Cell Biol 142: 557-571.

51. Wartenberg M, Fischer K, Hescheler J, Sauer H (2002) Modulation of intrinsic P-glycoprotein expression in multicellular prostate tumor spheroids by cell cycle inhibitors. Biochim Biophys Acta 1589: 49-62.

52. Masutani M, Nozaki T, Nakamoto K, Nakagama H, Suzuki H, Kusuoka, et al. (2000) The response of Parp knockout mice against DNA damaging agents. Mutat Res 462: 159-166.

53. Ratnam K, Low JA (2007) Current development of clinical inhibitors of poly(ADP-ribose) polymerase in oncology. Clin Cancer Res 13: 1383-1388.

54. McNealy T, Frey M, Trojan L, Knoll T, Alken P, et al. (2003) Intrinsic presence of poly (ADP-ribose) is significantly increased in malignant prostate compared to benign prostate cell lines. Anticancer Res 23: 1473-1478.

55. Wharton SB, McNelis U, Bell HS, Whittle IR (2000) Expression of poly(ADPribose) polymerase and distribution of poly(ADP-ribosyl)ation in glioblastoma and in a glioma multicellular tumour spheroid model. Neuropathol Appl Neurobiol 26: 528-35.

56. Watanabe M, Takagi A, Matsuzaki T, Kami D, Toyota M, et al. (2006) Knowledge of epigenetic influence for prostate cancer therapy. Curr Cancer Drug Targets 6: 533-551.

57. Sharma S, Kelly TK, Jones PA (2010) Epigenetics in cancer. Carcinogenesis 31: $27-36$

58. Graff JR, Gabrielson E, Fujii H, Baylin SB, Herman JG (2000) Methylation patterns of the E-cadherin 5' $\mathrm{CpG}$ island are unstable and reflect the dynamic, heterogeneous loss of E-cadherin expression during metastatic progression. $J$ Biol Chem 275: 2727-2732.

59. Storch K, Eke I, Borgmann K, Krause M, Richter C, et al. (2010) Threedimensional cell growth confers radioresistance by chromatin density modification. Cancer Res 70: 3925-3934.

60. Le Beyec J, Xu R, Lee SY, Nelson CM, Rizki A, et al. (2007) Cell shape regulates global histone acetylation in human mammary epithelial cells. Exp Cell Res 313: 3066-75.

61. Maynard MA, Ohh M (2007) The role of hypoxia-inducible factors in cancer. Cell Mol Life Sci 64: 2170-2180.

62. Francia G, Green SK, Bocci G, Man S, Emmenegger U, et al. (2005) Downregulation of DNA mismatch repair proteins in human and murine tumor spheroids: implications for multicellular resistance to alkylating agents. Mol Cancer Ther 4: 1484-1494.

63. Shahrzad S, Bertrand K, Minhas K, Coomber BL (2007) Induction of DNA hypomethylation by tumor hypoxia. Epigenetics 2: 119-125

64. Chen H, Yan Y, Davidson TL, Shinkai Y, Costa M (2006) Hypoxic stress induces dimethylated histone $\mathrm{H} 3$ lysine 9 through histone methyltransferase $\mathrm{G} 9 \mathrm{a}$ in mammalian cells. Cancer Res 66: 9009-9016.

65. Wouters BG, Weppler SA, Koritzinsky M, Landuyt W, Nuyts S, et al. (2002) Hypoxia as a target for combined modality treatments. Eur J Cancer 38: 240 257.

66. Ralph SJ, Rodríguez-Enríquez S, Neuzil J, Saavedra E, Moreno-Sánchez R (2010) The causes of cancer revisited: "mitochondrial malignancy" and ROSinduced oncogenic transformation - why mitochondria are targets for cancer therapy. Mol Aspects Med 31: 145-170.

67. Khandrika L, Kumar B, Koul S, Maroni P, Koul HK (2009) Oxidative stress in prostate cancer. Cancer Lett 282: 125-136.

68. Liu SK, Coackley C, Krause M, Jalali F, Chan N, et al. (2008) A novel poly(ADP ribose) polymerase inhibitor, ABT-888, radiosensitizes malignant human cell lines under hypoxia. Radiother Oncol 88: 258-268.

69. Rappa G, Mercapide J, Anzanello F, Prasmickaite L, Xi Y, et al. (2008) Growth of cancer cell lines under stem cell-like conditions has the potential to unveil therapeutic targets. Exp Cell Res 314: 2110-2122.

70. Miki J, Rhim JS (2008) Prostate cell cultures as in vitro models for the study of normal stem cells and cancer stem cells. Prostate Cancer Prostatic Dis 11:32 39. 